〔Med. Entomol. Zool. Vol. 55 No. 1 p. 11-20 2004]

\title{
A new species of Mimomyia (Ingramia) from Indonesia (Diptera: Culicidae)
}

\author{
Ichiro Miyagi $^{1)}$, Takako Toma ${ }^{1), 2)}$ and Yukiko HigA ${ }^{1)}$ \\ ${ }^{1)}$ Laboratory of Medical Zoology, School of Health Sciences, Faculty of Medicine, University of the \\ Ryukyus, 207 Uehara, Nishihara, Okinawa, 903-0215 Japan \\ ${ }^{2)}$ Center for Asia-Pacific Island Studies, University of the Ryukyus, Senbaru 1, \\ Nishihara, Okinawa, 903-0213 Japan
}

(Received: 3 October 2003; Accepted: 10 November 2003)

\begin{abstract}
Mimomyia (Ingramia) mogii is described as a new species from Flores Island, Indonesia. The larvae breed in water held by plants such as banana leaf sheaths, cut bamboos, taro leaf axils, and occasionally drum containers. The adults, male genitalia, pupa and larva are described in detail, photographed and illustrated, and keys to the Oriental species of the subgenus Ingramia are provided.
\end{abstract}

Key words: Mimomyia, Ingramia, phytotelmata, Mimomyia mogii, Indonesia

\section{INTRODUCTION}

This study is based on materials collected by the authors in 1997 while conducting a cooperative research project with Hasanuddin University, Indonesia entitled "Studies on the impact of rice field development on disease vectors in Indonesia". From these materials, an interesting new species of the genus Mimomyia was found.

Mimomyia was previously treated as a subgenus of the genus Ficalbia Theobald, but was resurrected to full genus by Mattingly (1971). The genus Mimomyia includes 3 subgenera, Mimomyia s. str. (17 species), Etorleptiomyia (6 spp.) and Ingramia (21 spp.) (Mattingly, 1957; Knight and Stone, 1977; Grjebine, 1986). The former two subgenera occur from tropical Africa through the Oriental Region with expansion into the Australasian Region as far as the Solomon Islands, but the latter is restricted to Madagascar, Comores Is. and the Oriental Region. After comparison with descriptions of all the known species of the genus described from the Oriental Region as well as Madagascar, we determined that the new species belongs to the subgenus Ingramia.

The terminology used for the adult male and female, male genitalia, larva and pupa follows Harbach and Knight (1980, 1981).

Mimomyia (Ingramia) mogii Miyagi, Toma et Higa, n. sp.

(Fig. 1A-D)

Female. Wing length $2.62 \mathrm{~mm}$.

Head: Vertex covered with pale and brown upright forked scales from center to posterior side, narrow scales anterior side; antennae about as long as proboscis; flagellomere 1, with white scales basally, about 1.2 length of flagellomere 2; eyes well separated; pedicel covered with pale scales; setae along margin of eyes. Proboscis with 2 pale bands at middle and apical quarter; maxillary palpus about a quarter of the length of proboscis, dark scaled, pale scales at middle and tip. 


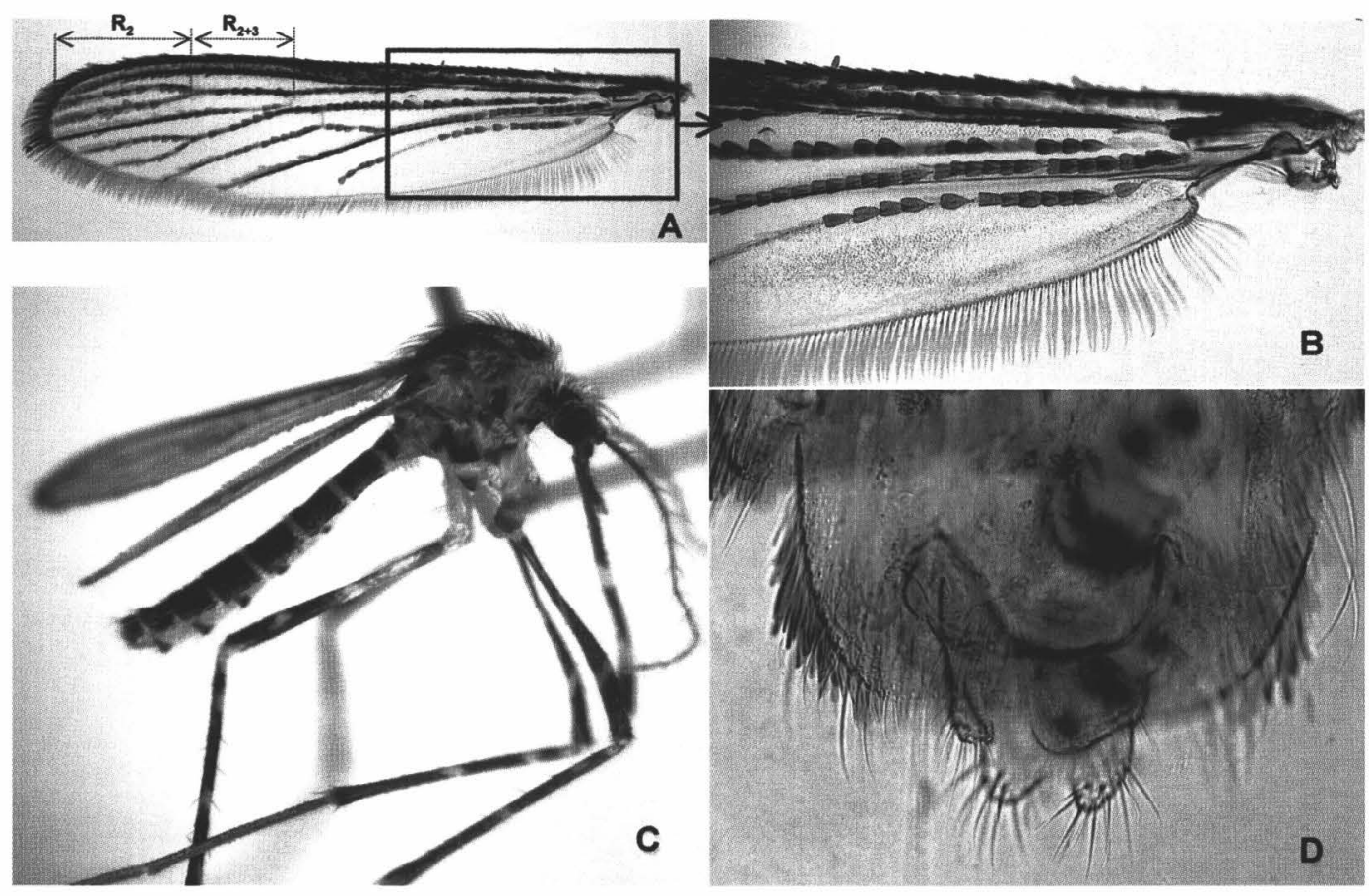

Fig. 1. Female of Mi. (Ingramia) mogii n. sp. (A) Wing. (B) Dark and pale scales of wing. (C) Lateral aspect of female. (D) female genitalia. $\mathrm{R}_{2}$, radius-two and cell; $\mathrm{R}_{2+3}$, radius-two-plus-three.

Scales on alula were lost during a mounting process.

Thorax: Integument of scutum dark brown, covered with narrow, curved, golden scales; acrostical setae absent; median anterior promontory setae present; more than 15 dorsocentral setae; about 5 strong setae in supraalar area; Scutal integument paler; median lobe of scutellum covered with broad black scales basally, broad white scales at middle part, narrow golden scales apically, narrow white scales in lateral lobes of scutellum, 2-5 scutellar setae in each lobe; mesopostnotum dark brown and bare; a patch of whitish setae at base of wing. Pleural integument dark brown; anterior part of postpronotum, subalare, lower part of mesokatepisternum and mesokatepimeron pale, postspiracular area and mid mesokatepisternum greatly dark; about 4 prealar setae present; postspiracular area with narrow yellowish scales at anterior side and flat white scales at posterior side; round and flat white scales scattered on upper half of mesokatepisternum and around lower mesokatepisternal setae; 2-5 upper and 3-8 lower mesokatepisternal setae present; more than 7 upper mesepimeral setae present; round and flat white scales scattered on upper half of mesanepimeron; postpronotum having narrow yellow scales in posterior half; about 5 postpronotum setae present; antepronotum with narrow yellow scales at lower posterior side, 6 setae at upper anterior side. Wing (Fig. 1A, B): Covered with large flat spatulate dark and pale scales; alula with broad scales; upper calypter with narrow scales; the Cell $\mathrm{R}_{2}$ about 1.3-1.6 length of $\mathrm{R}_{2+3}$; halter covered with small white and dark scales.

Legs: Upper anterior integument of forecoxa dark with white scales; upper midcoxal integument dark; white scaled anterior part of mid- and hindcoxae; each coxa having coxal setae; foreand mid femora with two pale bands, scattered with white scales; hind femur having two broad pale bands, in some specimens combined, white scaled apically, 2 setae at tip; all tibiae with a basal band and two others at middle and lower sides, occasionally pale patch in anteroapical part; hindtibia with 4 pale bands, occasionally apical two bands combined; foretibial claw not developed; fore-, mid-, hindtarsi almost dark scaled, with a few white scales basally and apically.

Ungues: Fore-, mid- and hindungues mostly equal in length with submedian tooth.

Abdomen (Fig. 1C): Tergum I entirely covered with dark scales, terga II-VIII dark scaled, each 


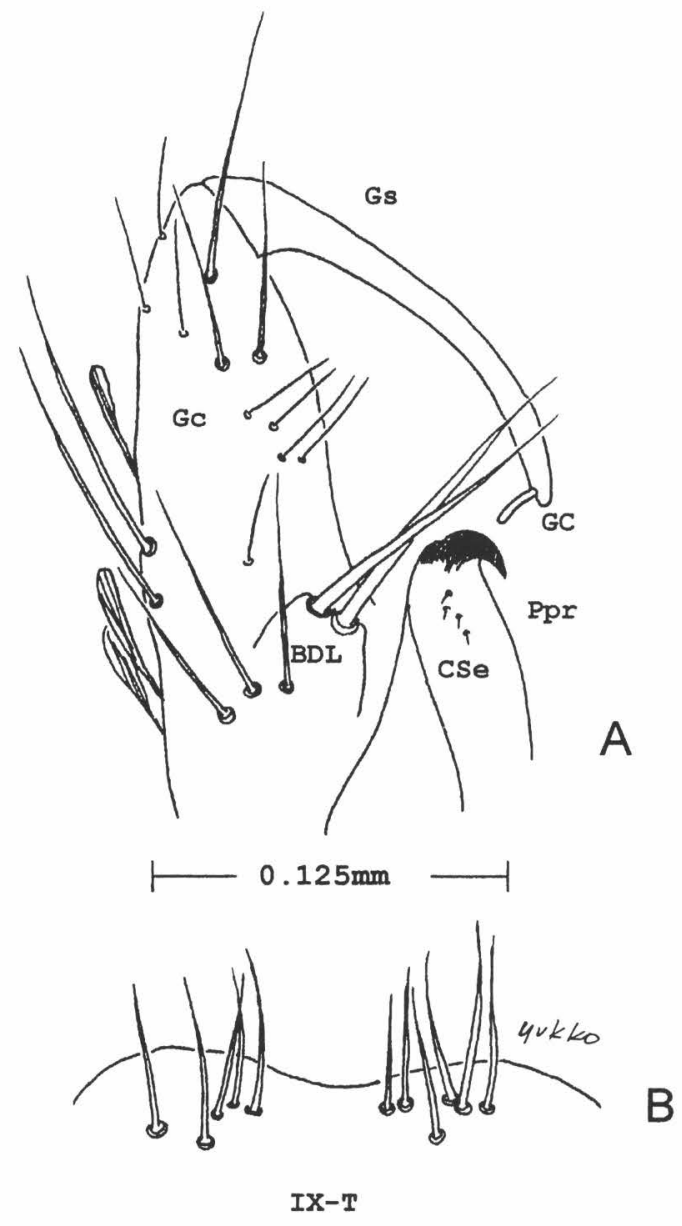

Fig. 2. Male genitalia of Mi. (Ingramia) mogii n. sp. (A) Dorsal aspects of male genitalia. (B) IX-tergum (IX-T). Gc, gonocoxite; GC, gonostylar claw; Gs, gonostylus; BDL, basal dorsomesal lobe; Ppr, paraproct; CSe, cercal seta. with basal pale band, in some specimens terga V-VII all covered with dark scales, white scales in the middle part of tergum VII; sternum I entirely white scaled, sterna II-VIII white scaled, each with apical dark patch, and with several dark scales basolaterally in sterna IIIVIII.

Male. Similar in general appearance to the female. Wing length $2.48 \mathrm{~mm}$.

Head: Maxillary palpus about 0.25 of proboscis, white scaled with 3 dark bands in small part. Proboscis covered with dark scales, pale band in middle, and apical third swollen with pale scales.

Abdomen: Tergum I dark scaled with a few white scales occasionally, some specimens having white scale patch in tergum VII, terga I-VIII with lateral spots, II-IV in some specimens; sterna II-VII with several dark scales basolaterally.

Genitalia (Fig. 2): Gonocoxite relatively narrow, about three times as long as its breadth at center, outer and dorsal surfaces of gonocoxite with numerous long brush-like setae. Basal dorsomesal lobes with 2 strong setae. Gonostylus narrow without setae, small stout tooth at apex. Paraproct crown with strong spine, 3 or 4 cercal setae on paraproct (Fig. 2A). 5 or 6 setae on IX-T (Fig. 2B).

Pupa. Chaetotaxy as illustrated in Fig. 3 and in Table 1. Abdomen 3.85-4.75 mm. Trumpet $1.41 \mathrm{~mm}$. Cephalothorax (CT) (Fig. 3A): Trumpet darkly pigmented at traocheoid, elongate; pinna 0.21 length of trumpet. Seta 6-CT fine, mostly single; 8-CT fine, single or double. Abdomen (Fig. 3B): Most of the setae simple and

reduced in branches. 1-II, III, IV, V, VI, VII, moderately pigmented, most developed among setae on each segment; 1-II usually single; 3 -II mesad of 1-II, single; 1-III single to triple; 1-IV 4-9 branched; 5-IV mesad of 1-IV, 2-4 branched; 1-V 4-8 branched; 5-V 3 or 4 branched; 1-VI 4-7 branched; 5-VI 3-5 branched; 1-VII 1-4 branched; 5-VII 3-6 branched; 4-VIII single or double; 9-VIII 4-12 branched; 14-VIII mostly single, shortest in the segment. Paddle (Fig. 3B, C): Oval-shape, with marginal long hair.

Larva. Chaetotaxy as illustrated in Fig. 4 and in Table 2. Head (Fig. 4A): Width 1.02 mm; brownish-yellow, 1.3 times as wide as long, seta 1-C robust, gradually tapering to a point, 3-C short and single, 4-C usually 2 branched, 5-C single or double, 6 -C little shorter than 5-C, 1-3 branched, 7-C caudad of 5-C, single, 8, 9, 10-C shorter than 7-C, mostly 2 branched, 11, 12-C usually single, 13$\mathrm{C}$ caudad of 12-C, usually 2 branches, 14-C 2-4 branched, mesad of 13-C, 15-C 2-4 branches. Antenna (Fig. 4A): Freely articulated, $0.26 \mathrm{~mm}$ long, short; 1-A single; apex of first articulated segment of antenna with 2 setae of single (2, 3-A); 4-A single in apex of distal articulated segment. Two types of mouth brushes well developed, one type lateral palatal brush-like, smooth and long, and the other teeth brush-like. Dorsomentum with about 10 teeth on each side (Fig. 4B). Maxilla 

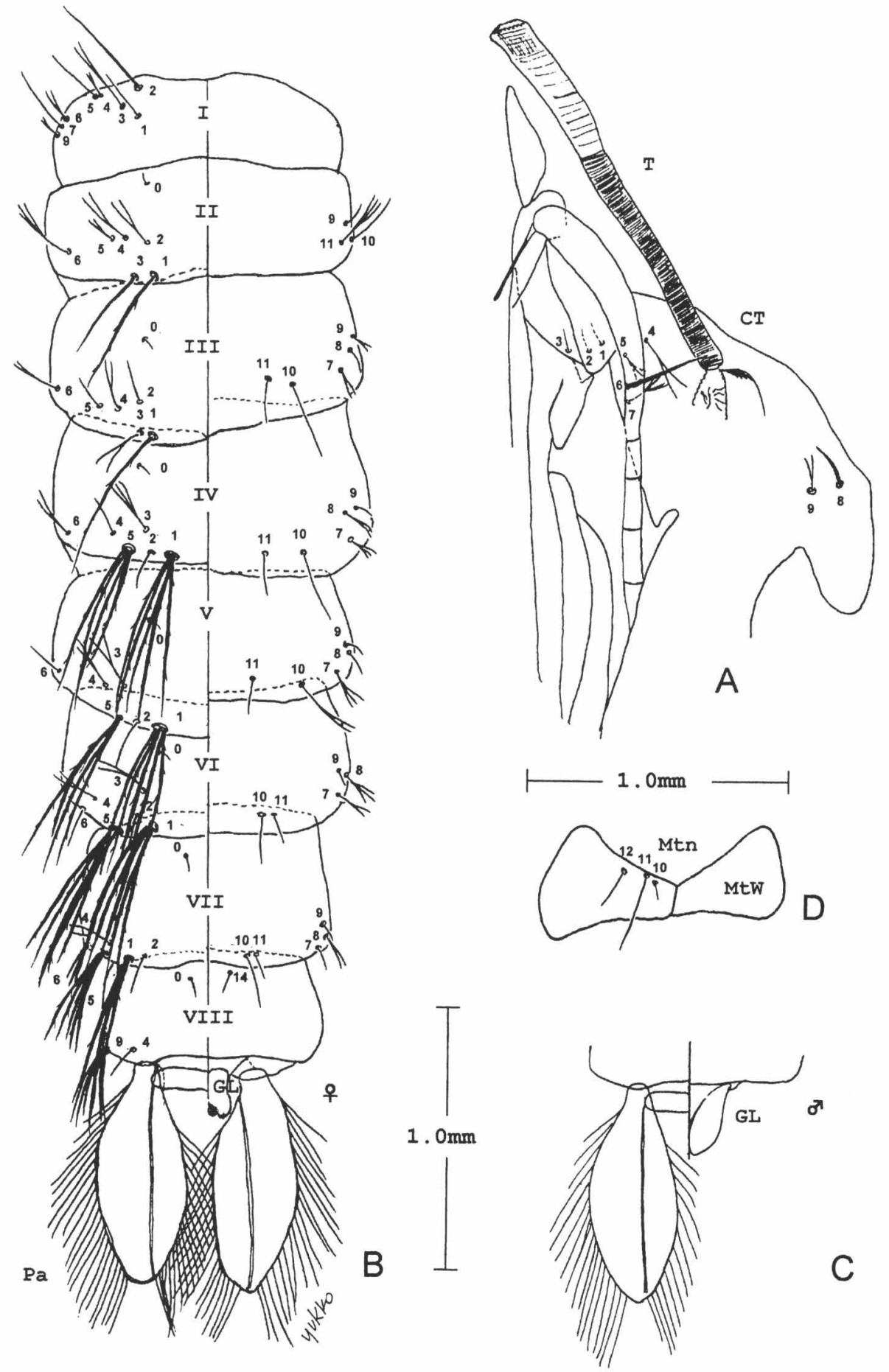

Fig. 3. Pupa of Mi. (Ingramia) mogii n. sp. (A) Cephalothorax (CT). (B) Abdomen of female. (C) Genital lobe (GL) of male. (D) Metanotum (Mtn). T, trumpet; MtW, metathoracic wing; Pa, paddle. 
Table 1. Chaetotaxy of the pupa of Mimomyia (Ingramia) mogii n. sp., based on 7 specimens.

\begin{tabular}{|c|c|c|c|c|c|c|c|c|c|}
\hline \multirow{2}{*}{ Seta no. } & \multirow{2}{*}{ Cephalothorax } & \multicolumn{8}{|c|}{ Abdomen } \\
\hline & & I & II & III & IV & $\mathrm{V}$ & VI & VII & VIII \\
\hline 0 & - & - & 1 & 1 & 1 & 1 & 1 & 1 & 1 \\
\hline 1 & 1 & $1-2(1)$ & $1-3(1)$ & $1-3(1)$ & $4-9(5)$ & $4-8(5)$ & $4-7(5)$ & $1-4(3)$ & - \\
\hline 2 & 1 & $1-2(1)$ & $1-3(2)$ & 1 & 1 & 1 & 1 & $1-2(1)$ & - \\
\hline 3 & $1-2(1)$ & $1-2(2)$ & 1 & $1-3(2)$ & $2-4(3)$ & $1-3(2)$ & $1-3(2)$ & - & - \\
\hline 4 & $1-4(2)$ & $2-4(2)$ & $1-3(2)$ & $1-3(2)$ & $1-2(1)$ & $2-4(3)$ & $1-3(2)$ & $1-4(2)$ & $1-2(1)$ \\
\hline 5 & $1-3(3)$ & 1 & $2-5(2)$ & $1-2(1)$ & $2-4(4)$ & $3-4(4)$ & $3-5(5)$ & $3-6(6)$ & - \\
\hline 6 & $1-3(1)$ & $1-5(2)$ & $1-5(3)$ & $1-4(2)$ & $1-5(1,2)$ & $1-3(1)$ & $1-3(1)$ & $2-5(3)$ & - \\
\hline 7 & $1-4(1,2)$ & $1-3(1)$ & - & $1-6(2)$ & $2-4(3)$ & $1-4(3)$ & $1-3(2)$ & $1-2(1)$ & - \\
\hline 8 & $1-2(1)$ & - & - & $1-2(1)$ & $1-3(2)$ & $1-3(1)$ & $1-2(1)$ & $1-4(2)$ & - \\
\hline 9 & $1-3(2)$ & $1-2(1)$ & $1-2(1)$ & $1-3(2)$ & $1-2(1)$ & $1-2(1)$ & $1-4(3)$ & $1-5(1)$ & $4-12(6)$ \\
\hline 10 & 1,2 & - & $1-2(1)$ & $1-2(1)$ & $1-2(1)$ & $1-3(2)$ & $1-3(1)$ & $1-3(1)$ & - \\
\hline 11 & 1,2 & - & $1-5(3)$ & $1-3(1)$ & $1-2(1)$ & $1-3(1)$ & $1-2(1)$ & 1 & - \\
\hline 12 & 2 & - & - & - & - & - & - & - & - \\
\hline 13 & - & - & - & - & - & - & - & - & - \\
\hline 14 & - & - & - & - & - & - & - & - & $1-2(1)$ \\
\hline
\end{tabular}

( ), mode of the number of the branches.

with strong setae at lower side and fine setae at upper side, one robust spine, 4-Mx single. Thorax (Fig. 4C): Setae moderately pigmented; 1-P single, 2-P mostly single; 3-P usually triple, mesad of 2P; 4-P short, 1-3 branched; 5-P 2-4 branched; 6-P mostly single, longer than 5-P; 7-P 2-6 branched; 8-P short, mostly 3 branches; 9 , 10-P single; 12 -P single, as twice in length as 9, 10-P; 14-P shorter than 8-P, 1-3 branched; 3, 4-M single; 5-M almost 3 times longer than 4-M; 9-M long, 3-5 branched; $10-\mathrm{M}$ as long as 9-M, mostly 3 branched; 12 -M slightly shorter than 9, 10-M, 2 or 3 branched; 11-P shorter than 12-P, usually single; strong and short spine at the same level of base of 9, 10, 11, 12-P; setae on metathorax relatively smaller than those on meso-, prothorax; 9-T 3-5 branched, longest among setae on metathorax; 10-T mostly 3 branches; $12-\mathrm{T}$ single, one-third in length of 9-T. Abdomen (Fig. 4D): Most of the setae reduced in branches; 6-I, II, III, IV, V most developed among setae on each segment; 6-III, IV mostly 4 branched; 6-V 2 or 3 branched; 7-I, II single or double. Comb scales thorn-shaped, consisting of 5-9 scales on each side, a few scales with small lateral denticles (Fig. 4E, F). Siphon (Fig. 4F): Index 2.56; lightly pigmented, darkened on basal ring, without pectin teeth; 1-S arising at half level from the basal, 2 or 3 branched. Segment X (Fig. 4F): Saddle incomplete, moderately pigmented, with spine-like spicules on posterior margin; 1-X single, moderately pigmented; 2 -X mostly 3 branched, twice as long as 1-X; 3 -X 1-3 branched; 4 -X one paired, short, 1-4 branched. Anal papillae elongate and blunt.

Type Material. Holotype: female (970805-3 with associated larval and pupal excuviae and left wing on a slide 970805-3-18) from banana stem sheath in Kelimuto, Flores Island. Paratype: male (970809-20 with genitalia on a slide 970809-20-G90) from cut bamboo in Muamure; 2 females (970805-7 with associated genitalia on a slide $970805-7-\mathrm{G}-91$ and $970807-10$ with associated wing and genitalia on slides 970807-10-G-92) from banana stem stump in Kelimuto and drum container in Saga, respectively; female on a slide 970812-11 from banana leaf sheath in Lowotoro; 5 females on pins 970805-3 ( 1 specimen) from banana leaf sheath in Kelimuto, 970807-10 (3 specimens) from drum container in Saga, 970809-20 (1 specimen) from cut bamboo in Muamure; 6 larvae on slides 970805-3 from banana leaf sheath in Kelimuto; 6 pupal excuviae on slides 970805-3 (2 specimens) from banana leaf sheath in Kelimuto and 970807-10 (4 specimens) from drum container in Saga. The holotype and some paratypes will be deposited in the National Museum of Natural History, Smithsonian Institution, Washington, DC, U.S.A.

Etymology. We are delighted to name this species in honor of Dr. Motoyoshi Mogi of 


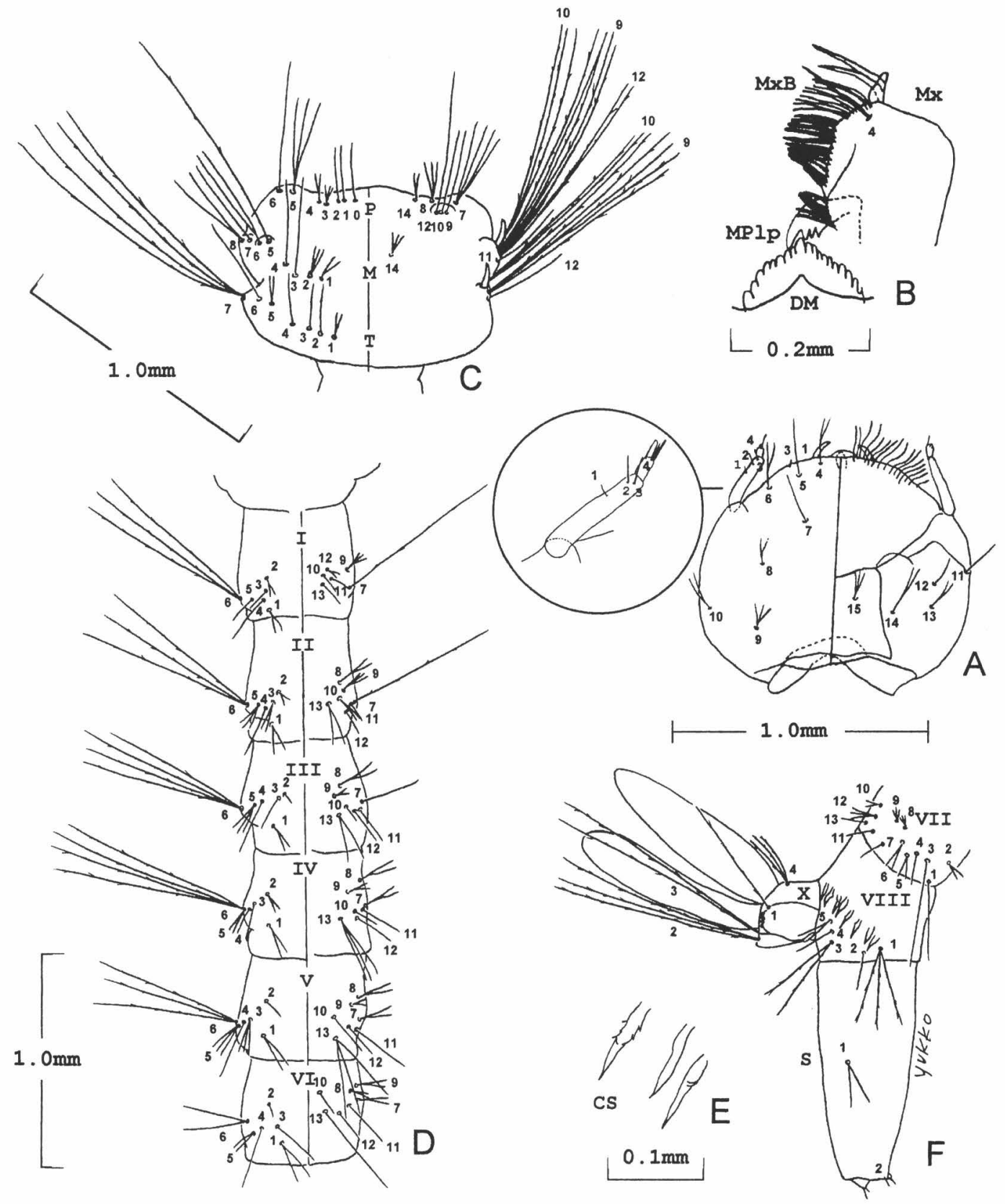

Fig. 4. Larva of Mi. (Ingramia) mogii n. sp. (A) Head. (B) Mentam plate and maxillary palpus. (C) Thorax. (D) Abdominal segments. (E) Comb scales (CS). (F) Terminal abdominal segments. P, prothorax; M, mesothorax; T, metathorax; S, siphon; I-X, abdominal segments; Mx, maxilla; MxB, maxillary brush; MPlp, maxillary palpus; DM, dorsomentum.

Saga University, Japan, for his contributions to medical education, to enrichment of scientific information in the field of mosquito ecology in Japan and Indonesia, and his encouragement of our research in Flores Is., Indonesia. 
Table 2. Chaetotaxy of the larva of Mimomyia (Ingramia) mogii n. sp., based on 6 specimens.

\begin{tabular}{|c|c|c|c|c|c|c|c|c|c|c|c|c|}
\hline \multirow{2}{*}{ Seta no. } & \multirow{2}{*}{$\begin{array}{c}\text { Head } \\
\mathrm{C}\end{array}$} & \multicolumn{3}{|c|}{ Thorax } & \multicolumn{8}{|c|}{ Abdomen } \\
\hline & & $\mathrm{P}$ & M & $\mathrm{T}$ & I & II & III & IV & $\mathrm{V}$ & VI & VII & VIII \\
\hline 0 & - & 1 & - & - & - & - & - & - & - & - & - & - \\
\hline 1 & 1 & 1 & $1-2(2)$ & $1-3(2)$ & $1-2(2)$ & $2-3(2)$ & $2-3(2)$ & $2-3(2)$ & $2-3(2)$ & 2 & $1-2(2)$ & $2-4(3)$ \\
\hline 2 & - & $1-3(1)$ & $1-3(3)$ & 1 & $1-3(2)$ & $1-3(2)$ & $1-2(1)$ & $1-2(2)$ & $2-2(1)$ & $1-2(1)$ & 1,2 & 1 \\
\hline 3 & 1 & 3 & 1 & $1-2(1)$ & $2-4(2)$ & $2-4(3)$ & $1-2(1)$ & 1 & $2-3(3)$ & 1 & $1-3(1,2)$ & $2-3(2)$ \\
\hline 4 & $1-2(2)$ & $1-3(2)$ & 1 & $1-3(1)$ & 1 & 1 & 1 & $1-2(1)$ & 1 & $1-2(1)$ & 1 & 1 \\
\hline 5 & $1-2(1)$ & $2-4(3)$ & 1 & $1-2(2)$ & 1 & $1-4(3)$ & $2-4(3)$ & $2-4(2)$ & $2-4(3)$ & $2-3(2)$ & $2-3(2)$ & $2-3(2)$ \\
\hline 6 & $1-3(2)$ & $1-2(1)$ & $1-2(2)$ & 1 & $2-8(3)$ & $3-4(3)$ & $3-4(4)$ & $2-4(4)$ & $2-3(3)$ & 2 & $1-3(2)$ & 1-A, 1 \\
\hline 7 & 1 & $2-6(4)$ & 1 & $2-5(4)$ & $1-2(1)$ & $1-2(1)$ & $1-2(1)$ & $2-3(2)$ & $2-3(2)$ & 2,3 & $1-3(1)$ & $2-\mathrm{A}, 1$ \\
\hline 8 & $2-3(2)$ & $2-4(3)$ & $2-3(2)$ & - & - & $2-3(2)$ & $1-2(2)$ & $1-2(2)$ & 1,2 & $2-3(2)$ & $2-4(3)$ & $3-\mathrm{A}, 1$ \\
\hline 9 & 2,3 & 1 & $3-5(4)$ & $3-5$ & $2-4(2)$ & $2-3(2)$ & 2 & $1-2(2)$ & $1-2(2)$ & 2 & $2-3(3)$ & 4-A, 1 \\
\hline 10 & $1-3(2)$ & 1 & $2-3(3)$ & $3-4(3)$ & 1 & 1,2 & 1 & 1 & 1 & $1-2(1)$ & $1-2(1)$ & $1-\mathrm{S}, 2-3(2)$ \\
\hline 11 & $1-2(1)$ & - & $1-2(1)$ & - & $1-2(1)$ & $1-2(2)$ & 1 & 1 & 1 & $1-2(1)$ & 1 & $1-\mathrm{X}, 1$ \\
\hline 12 & $1-2(1)$ & 1 & 2,3 & 1 & $2-4(3)$ & $1-2(1)$ & $1-2(1)$ & 1 & 1 & $1-3(1,2)$ & $1-3(3)$ & $2-\mathrm{X}, 2-3(3)$ \\
\hline 13 & $1-3(2)$ & - & - & - & 1 & $2-4(3)$ & $2-3(3)$ & $2-3(3)$ & $2-3(3)$ & $1-2(1)$ & $1-2(1)$ & $3-X, 1-3(2)$ \\
\hline 14 & $2-4(2)$ & $1-3(2)$ & 3,4 & - & - & - & - & - & - & - & - & $4-X, 1-4(3)$ \\
\hline 15 & $2-4(3,4)$ & - & - & - & - & - & - & - & - & - & - & Comb, 5-9 $(6,7)$ \\
\hline
\end{tabular}

( ), mode of the number of the branches. 


\section{Taxonomic discussion}

Mimomyia mogii n. sp. apparently belongs to the genus Mimomyia, with its larval habitats specialized among subgenera Mimomyia, Etorleptiomyia and Ingramia (Mattingly and Grjebine, 1958; Mattingly, 1971; Grjebine, 1986). The former two subgenera breed in ponds, marshes and paddy fields, while the lastter in tree holes, leaf axils and bamboo holes, which we call phytotelmata (Mattingly and Grjebine, 1958; Grjebine, 1986; Toma and Miyagi, 1986; Mogi, 1999, 2000). Mimonyia mogii n. sp. was collected from banana leaf sheaths, cut bamboos, taro leaf axils, and occasionally drum containers, exhibiting larval habitat of the subgenus Ingramia.

Morphological characteristics of $\mathrm{Mi}$. mogii n. sp. are as follows; flagellomere 1 about 1.2 length of flagellomere 2, alula with broad scales, the Cell $\mathrm{R}_{2}$ about 1.3-1.6 length of $\mathrm{R}_{2+3}$, male maxillary palpus about one-fourth of the length of proboscis, pupal 1-I small and single, pupal seta 9-VIII large and 4-12 branched, shorter larval antenna, single or bifid of larval seta $2-\mathrm{S}$, less than 3 pairs of 4 -X in larva, all of which are the important characteristics of the subgenus Ingramia (Mattingly, 1957; Tanaka et al., 1979; Grjebine, 1986). Although a few characteristics (upper calypter with narrow scales and postspiracular scales) of Mi. mogii n. sp. are common to those of the subgenus Etorleptiomyia, this species should be placed in the subgenus Ingramia, because the characteristic of wing vein and larval siphonal seta 2 -S associated with larval breeding in plant container habitats are of great taxonomic value for subgeneric identification of the genus Mimomyia (Mattingly, 1957; Grjebine, 1986).

However, Mi. mogii n. sp. has some unique morphological characteristics, none of which the species of the subgenus Ingramia exhibits, such as 1 pair of larval seta 4 -X and oval-shaped pupal paddle. Therefore, as to the subgeneric status of Mi. mogii n. sp. revisional study may be required in future with more specimens of other known species and new species in the genus Mimomyia.

After detailed studies of mosquitoes of the genus Mimomyia in the Ethiopian and the Oriental Regions by Mattingly (1957), Grjebine (1986), Doucet (1951) and White (1974), all of the 21 species of the subgenus Ingramia could be further classified into 3 groups, i.e., Group A, Group B and Group C (Grjebine, 1986). They are distinguished by differences in morphology of pale scales on wings, presence/absence of prealar setae and acrostical setae, and the number of setal branches in antenna 2, 3 and 4-A in larvae (Grjebine, 1986). Group A (10 species) and B (8 species) were reported from Madagascar and Comores Is., and Group C (3 species) was from the Oriental Regions (fusca from Madagascar also). Mimomyia mogii n. sp. has pale scales on wings, prealar setae, no acrostical setae and single 2, 3 and 4-A in larvae, respectively. Therefore Mi. mogii n. sp. is assigned to Group A of the subgenus Ingramia. This is the first record of the group from the Oriental Regions.

Table 3. Major morphological differences between known species of Group A of subgenus Ingramia and Mimomyia (Ing.) mogii n. sp. from Floress Island, Indonesia.

\begin{tabular}{lcc}
\hline \hline & Group A & mogii n. sp. \\
\hline Larval head setae $^{1}$ & Stellate/branch-tipped and long & Single/double/triple and short \\
Pupal paddles ${ }^{2}$ & Long and narrow & Oval-shaped \\
(paddle index) & $(8.6-23)$ & $(2.3-3.1)$ \\
Male maxillary palpus/Proboscis & $0.4-0.8$ & 0.25 \\
Apical pale band & No apical pale band & Distal third \\
on male proboscis ${ }^{3}$ & & (with some dark scales) \\
\hline
\end{tabular}

${ }^{1}$ Larvae of martinei unknown; ${ }^{2}$ Pupae of martinei unknown; ${ }^{3}$ No descriptions for levicastilloi and ramalai, and males of martinei unknown. 
Group A includes 10 species as follows; brygooi Grjebine 1986, grjebinei (Brunhes) 1977, levicastilloi Grjebine 1986, longicornis Grjebine 1986, martinei (Doucet) 1951, milloti Grjebine 1986, ramalai Grjebine 1986, roubaudi (Doucet) 1950, spinosa (Doucet) 1951 and stellata Grjebine 1986. In comparisons with descriptions and illustrations of the 10 species, Mi. mogii n. sp. has a number of differences in adult, larval and pupal stages. Major differences between the Madagascar species of Group A and Mi. mogii n. sp. are shown in Table 3.

Distribution. At present, known only from Flores Island, Indonesia.

Bionomics. Larvae were collected in banana leaf sheaths, cut bamboos, taro leaf axils and occasionally drum containers. It is unlikely that the adult females feed on men. This species may be of no medical importance.

\section{Keys to the Oriental species of the subgenus Ingramia}

Females

1. Wings spotted with white scales; acrostical setae absent mogii n. sp.

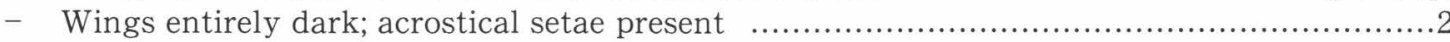

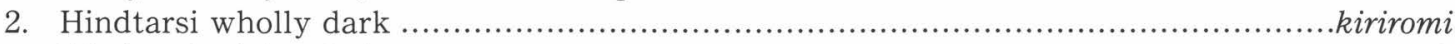

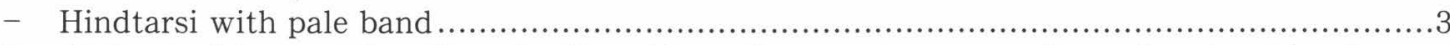

3. Abdominal terga with well-marked basal lateral spots; sterna conspicuously pale, at least

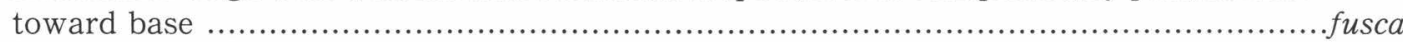

- Abdominal terga and sternites wholly dark .........................................deguzmanae

Males

1. Wings spotted with white scales; acrostical setae absent; maxillary palpus one fourth of the length of proboscis .................................................................

- Wings entirely dark; acrostical setae present; maxillary palpus usually more than half

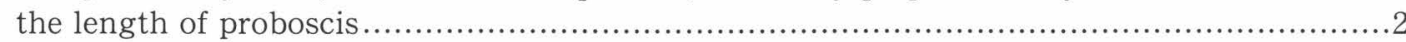

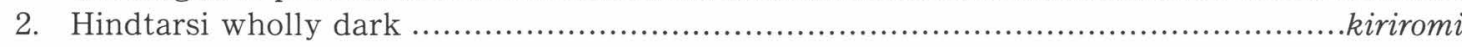

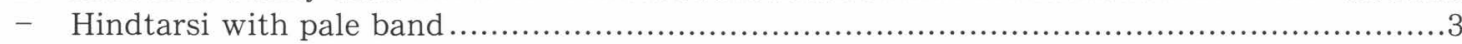

3. Maxillary palpus at most half the length of proboscis; terga and sterna with pale markings

- Maxillary palpus at least three fifths of the length of proboscis; terga and sterna wholly dark deguzmanae

Fourth-instar larvae (The larvae of kiriromi is unknown)

1. Siphon short (siphonal index about 2.6); setae 2 and 3-A single; 4 -X one pair ......mogii $\mathrm{n}$. sp.

- Siphon relatively long (siphonal index 4.5-7.5); setae 2 and 3-A numerous branched; 4-X

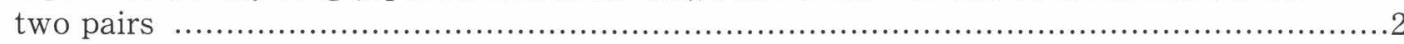

2. Comb teeth mostly simple ..............................................................fusca

- Comb teeth deeply incised, each with three or more prongs (the teeth expanded apically and divided into $4-5$ strong points) deguzmanae

\section{ACKNOWLEDGMENTS}

We thank LIPI (Indonesian Institute of Sciences, Jakarta) and Mr. B. Hasanuddin (Rector, Hasanuddin University, Ujung Pandang) for approval of this study. Thanks are also due to Mr. M. Y. Gayo (East Region Implementation, DGWRD, Ministry of Public Work, Jakarta) for his help during the study; Dr. M. Mogi (Saga Medical School) for 
excellently organizing the project involving this study; Mr. K. Miyagi (President of the Ocean Health Corporation, Okinawa) for providing us with suitable environment for this study. This study was supported by a Grant-in-Aid for Monbukagakusho International Scientific Research Program (Field Research) (No. 08041179).

\section{REFERENCES}

Doucet, J. 1951. Les moustiques de la region de Perinet. Memoires de l'institut scientifique de Madagascar, (A) 6: $63-82$.

Grjebine, A. 1986. Faune de Madagascar 68. Insectes Dipteres Culicidae Culicinae Ficalbiini. 441 pp. Museum national d'Histoire naturelle, Paris.

Harbach, R. E. and Knight, K. L. 1980. Taxonomists' Glossary of Mosquito Anatomy. 415 pp. Plexus Publishing, Inc. Marlton, New Jersey.

Harbach, R.E. and Knight, K. L. 1981. Corrections and additions to Taxonomists' Glossary of Mosquito Anatomy. Mosq. Syst. 13: 201-217.

Knight, K. L. and Stone, A. 1977. A catalog of the Mosquitoes of the World (Diptera: Culicidae) (2nd ed.). 611 pp. Entomological Society of America, Maryland.

Mattingly, P. F. 1957. The Culicine mosquitoes of the Indomalayan area. Part I Genus Ficalbia Theobald. 61 pp. British Museum, London.

Mattingly, P. F. 1971. Contributions to the mosquito fauna of Southeast Asia. XII. Illustrated keys to the genera of mosquitoes (Diptera, Culicidae). Contrib. Am. Entomol. Inst., 7: 1-84.

Mattingly, P. F. and Grjebine, A. 1958. Revision du genre Ficalbia Theobald et discussion de la position systematique des Ravenalites Doucet. Memoires de l'institut scientifique de Madagascar. Serie E-Teme IX. pp. 259-288.

Mogi, M. 1999. Phytotelmata: Small Habitats Support Biodiversity. 213 pp. Kaiyusya Publishers, Tokyo. (In Japanese)

Mogi, M. 2000. Phytotelmata: Cryptic mosquito habitats. In. Mosquitoes and Mosquito-borne Diseases (ed. Ng, F. S. P. and Yong, H. S.), pp. 255-272. Akademi Sains Malaysia, kualaLumpur.

Tanaka, K., Mizusawa, K. and Saugstad, E. S. 1979. Mosquitoes of Japan and Korea. A revision of the adult and larval mosquitoes of Japan (including the Ryukyu Archipelago and the Ogasawara Islands) and Korea (Diptera: Culicidae). Contrib. Am. Entomol. Inst., 16: 1-987.

Toma, T. and Miyagi, I. 1986. The mosquito fauna of the Ryukyu Archipelago with identification keys, pupal descriptions and notes on biology, medical importance and distribution. Mosq. Syst., 18: 1-175.

White, G. B. 1974. Priority of Ingramia Edwards, 1912, over Ravenalites Doucet, 1957 as the name for a subgenus of Mimomyia Theobald, 1903 (Diptera: Culicidae). Mosq. Syst., 6: 239-242. 